\title{
PHYSIOLOGICAL ASPECTS OF GENETICS ${ }^{1}$
}

\author{
By G. W. BEADLE \\ Kerckhoff Laboratories of Biology, California Institute \\ of Technology, Pasadena, California
}

The biological sciences appear to be in the midst of a period of unprecedented progress. An important salient in the advance is the general recognition of the significance of genes in the economy of the organism. The change is largely one in point of view. Many biologists have for a long time appreciated the basic nature of the gene and its role in development and function, but these relatively enlightened individuals have for the most part belonged to a small group of specialists that has tended to remain in isolation. The restraining fences are now being broken down with gratifying rapidity. Biochemists have begun to think in terms of genes because it has been demonstrated to them not only that the chemical reactions which make up living systems are under the fairly immediate supervision of these units of inheritance, but also that genetics provides a powerful tool with which a great deal can be learned about metabolic systems. In bacteriology, too, one sees the effects of an altered point of view toward genetics. Only a few years ago a bacteriologist who so much as raised the question of the existence of genes in bacteria was regarded as a renegade and heretic by his more orthodox fellowmen. It has now become acceptable to speak of bacterial genes; in fact, a recognized field of bacterial genetics has grown up almost over night (1).

Several general reviews of the field of genetics have appeared since Danforth's (2) contribution to this series (3 to 8). British wartime achievements in genetics have been summarized in the first number of the new Journal Heredity (9). In the same issue is found a most valuable bibliography of genetic papers published in Italy and Germany during the war years, 1939 to 1945 (10). The eleventh volume of the Cold Spring Harbor Symposia on Quantitative Biology entitled Heredity and Variation in Microorganisms (11) constitutes a series of vivid expressions of the new viewpoints in genetics applied to bacteria, viruses and other microorganisms. The first volume of a series of annual reports on Symposia of the

${ }^{1}$ This review covers the period from January 1, 1946 to July 15, 1947. 
Society of Experimental Biology (British) has just appeared (11a). It contains nineteen significant and timely papers on nucleic acids.

The present reviewer has chosen for special consideration several topics in physiological or chemical genetics in which it appears that particularly significant developments are taking place. Limitations in space as well as in time, industry and insight of the author have precluded adequate consideration of other lines of work that may in the long run prove to be of even greater significance. In this latter category are recent additions to our knowledge of chromosome chemistry. It is not now clear to the reviewer just what are the interrelations of the genoprotein-T of Stern et al. (12), the chromosin of Mirsky \& Pollister $(13,14)$ and the chromosomin of the Stedmans (15). Progress continues to be made in immunogenetics as evidenced by the reviews of Irwin $(16,17)$, additional work on inherited cellular antigens in pigeons and doves (18), and further interpretations of the data on $R h$ blood types in man (19, 20,21). Additional experimental and theoretical consideration has been given to the phenomenon of position effect by Stern and his co-workers $(22,23)$, Gersh \& Ephrussi (24), and by Goldschmidt (25). Among other advances in physiological genetics that cannot be adequately treated here are the determination of pigment-granule characteristics in a number of mouse coat-color types (26), the chromatographic fractionation of the red pigments of the Drosophilia eye (27), the relation of the eye pigmentation to protein composition in Ephestia (28), studies on multiple alleles and modifier genes $(29,30,31)$, and the effect of infrared radiation on the effectiveness of $\mathrm{x}$-rays in producing mutations (32).

\section{Genes AND Biosynthesis}

Production and detection of biochemical mutations.-During the past half dozen years many mutant strains of microorganisms with altered growth-factor requirements have been studied. The frequency with which these arise may be greatly increased by treatment with ionizing radiation, ultraviolet radiation, and certain chemicals. The method of producing and detecting growth-factor mutants in Neurospora has been described in detail by Beadle \& Tatum (33). It consists in testing individually numerous strains for ability to grow on a minimal medium. Essentially the same method has been used extensively by Fries (34) for detecting mu- 
tant strains in the Ascomycete Ophiostoma. Recently Fries (35) has developed a technique of filtering out and discarding the descendant mycelia of spores that germinate and grow on basal medium. In this way he has increased the frequency of the mutant strains among tested individuals by a factor of approximately eight. Because of the strong tendency to heterocaryon formation in Neurospora it seems unlikely that the Fries technique can be applied without modification in this organism. Lederberg \& Tatum (36) have devised a procedure for bacteria by which nonmutant individuals able to grow on the basal medium are allowed to produce colonies on an unsupplemented agar medium. After the locations of these are noted, mutant individuals are "developed" by pouring over the culture plate an agar medium with suitable additions. This method should be applicable to any colonial type microorganism. The use of colonial type mutants of filamentous fungi should make its use practicable in these organisms.

In the case of mutant strains of microorganisms that are capable of growth on a medium on which the original strain fails to grow, the classical enrichment technique of bacteriology can be used. This permits the examination of astronomical numbers of individuals. It has been applied to the measurement of mutation frequencies in bacteria (1), and in the study of back-mutation in Neurospora $(37,38)$. If a method comparable in efficiency with the enrichment technique could be devised for mutants with increased grow th factor requirements, progress in chemical genetics could be enormously accelerated.

Genes controlling vitamin synthesis.--Numerous instances of inherited inability of Neurospora strains to synthesize specific vitamins of the B group have been reported (5). Tatum \& Bell (39) have studied four mutant strains of this fungus that require thiamin or a related compound for growth. Each of these differs from wild type in a single gene. In one strain thiazole synthesis is blocked and in another the mold is unable to couple the thiazole and pyrimidine halves of the thiamin molecule. Two other mutants appear to be of a more complex nature. Monomethylaminoethanol has been shown by Horowitz (40) to be a normal precursor of choline. One mutant of the Neurospora that cannot make choline accumulates it while another is able to use it in place of choline. Mitchell \& Houlahan (41) have investigated a riboflavinless $\mathrm{Neu}$ rospora mutant strain that grows normally without exogenous 
riboflavin at $25^{\circ} \mathrm{C}$. and lower temperatures but gives little or no growth in the absence of this vitamin when grown at $28^{\circ} \mathrm{C}$. or a higher temperature. Three Neurospora mutant strains that require nicotinic acid or a related compound have been reported by Bonner $\&$ Beadle (42). When grown under appropriate conditions, one of these mutants accumulates a precursor that can be used by another. This precursor of nicotinic acid is a pyridine compound but has not yet been completely identified. Recently Beadle, Mitchell \& Nyc (43) have shown that one of the "nicotinicless" mutants grows when supplied indole, tryptophane, or kynurenine. The study of this mutant strain gives strong support to the hypothesis, based on work with mammals, that nicotinic acid is normally formed from tryptophane. The Neurospora evidence suggests that kynurenine is a normal intermediate in this process.

Numerous vitamin-requiring mutants of Ophiostoma have been obtained and studied by Fries (35). There are interesting differences in the relative frequencies of various types of mutants in Neurospora and Ophiostoma but the significance of these is not understood.

In connection with attempts to produce mutant strains of Penicillium notatum with increased penicillin-producing abilities, a number of growth-factor mutants were isolated (44). Many of these require specific vitamins for growth. Since this species has no perfect stage, inheritance studies by classical methods cannot be made.

Lindegren \& Lindegren (45) have recently made crosses between strains of yeasts (Saccharomyces) differing in ability to synthesize certain vitamins of the $B$ group. It is found that ability to synthesize pantothenic acid is differentiated by a single gene from inability to synthesize this vitamin. Similar relations are found between genes and ability to grow without exogenous thiamin, pyridoxin or $p$-aminobenzoic acid.

Biosynthesis of amino acids.-Examination of the properties of Neurospora and Penicillium mutants requiring arginine or a related compound for growth has prompted Bonner $(44,46)$ to suggest that glutamic acid and proline may be related to ornithine synthesis according to the following scheme:

$\rightarrow$ Glutamic acid $\rightarrow$ Intermediate $\rightarrow$ Ornithine $\rightarrow$ Citrulline $\rightarrow$ Arginine $\Uparrow 1$
Proline 
Six types of mutant strains are known. In each, one of the six reactions indicated in the scheme is assumed to be blocked.

A mutant strain of Neurospora that has been difficult to understand in terms of a single blocked reaction is one that requires for growth the amino acids isoleucine and valine. A recent reinvestigation of this mutant by Bonner (47) indicates that the conversion of the keto acid analogue of isoleucine to isoleucine is blocked and that $\alpha$-keto- $\beta$-methyl- $n$-valeric acid accumulated as a result of the interrupted reaction secondarily interferes with a reaction by which the $\alpha$-ketoisovaleric acid is converted to valine.

A common class of mutants in Neurospora (48), Ophiostoma (49), Penicillium (44), and the bacterium Escherichia coli $(50,51$, 52 ) is that in which sulfur metabolism is interfered with in one way or another. In some strains sulfate cannot be reduced to sulfite, in others any of a number of forms of organic sulfur can be used, and in still others, specific sulfur-containing amino acids must be supplied for normal growth. In studying the growth requirements of certain mutant strains in this category in Neurospora, Horowitz (48) has recently suggested that Neurospora synthesizes methionine as follows:

$$
\mathrm{SO}_{4}{ }^{-} \rightarrow \mathrm{SO}_{8}-\rightarrow \rightarrow \text { Cysteine } \rightarrow \text { Cystathionine } \rightarrow \text { Homocysteine } \rightarrow \text { Methionine }
$$

Cystathionine has been isolated from the mutant strain that cannot cleave it to form homocysteine. There is little doubt that it is the compound by which sulfur is transferred from a three carbon to a four carbon amino acid.

Other gene-directed syntheses.-Mitchell \& Houlahan (53) have analyzed a number of purine-requiring mutant strains of Neurospora. Seven genetically distinct types were identified. Inosine is a precursor of adenosine and is itself presumed to be formed from a hypothetical precursor by a gene-controlled reaction. The postulated precursor apparently is not accumulated by the mutant strain that cannot convert it to inosine but is instead irreversibly converted to a purple pigment. Mutants in which purine metabolism is defective are relatively frequent in Penicillium (44), and in Ophiostoma (54). The studies of Fries on purine-requiring mutants of Ophiostoma agree with those of Mitchell \& Houlahan in indicating inosine as a precursor of adenosine. A number of pyrimidinerequiring mutants have been found in both Ophiostoma (54) and Neurospora (5). 
Emerson \& Cushing (55) and Emerson (56) have reported two mutant strains of Neurospora, one that tolerates sulfonamide concentrations that would completely prevent growth of the original wild type, and another that actually requires a sulfonamide for growth. While studies of these strains have not as yet revealed the precise role of sulfonamides in cellular metabolism they seem to indicate quite clearly that these compounds do not act merely to displace $p$-aminobenzoic acid from the site in which it is needed for normal functioning of the cell.

These several examples of gene-directed chemical reactions add substantially to those previously known (5) and serve further to support the view that most of the chemical reactions by which organisms develop and function are under the fairly immediate supervision of genes.

\section{Mechanism of Gene Action}

The view that some genes act by controlling enzyme specificities is not new, but experimental evidence supporting it has not been impressive until relatively recently (5). Within the past several years many genetic traits have been studied in which primary gene action appears to be the control of specific chemical reactions. In a few instances such control can be shown to be through the mediation of enzymes. Mitchell \& Houlahan (53) have shown that in a specific one-gene mutant form of Neurospora the ability to aminate inosine to give rise to adenosine has been lost. McElroy \& Mitchell (57) found no detectable difference in the adenosine deaminase of the mutant and its wild type counterpart. It is possible that this deaminase is not the enzyme that catalyzes the reverse reaction, or that inosine amination is not the reaction primarily involved in the mutant strain.

Ginsburg \& Kaplan (58) have presented evidence that a skin oxidase present in wild-type mice is deficient in strains homozygous for mutant alleles of the coat color gene $C$.

A consideration of cases in which gene mutations are correlated with specific chemical reactions had led to the formulation of the hypothesis that primary gene action in general lies in directing the synthesis of specific proteins and that genes bear a one-to-one relation to such proteins (5). This would mean that enzymes directing specific chemical reactions should bear such a relation to the genes from which their specificities are copied. Delbrück [discussion fol- 
lowing paper by Bonner (46)] has raised the question as to whether the experimental data on which this hypothesis is based have not been automatically selected to favor it. If a gene were to control in a primary way the specificities of say three enzymes, an organism carrying only inactive mutant forms of this gene would fail in three corresponding reactions and, unless three reaction products were supplied to it from an outside source, it would have a small chance of surviving. In an organism like Neurospora, mutants of this kind would be likely to be lethal in practice because in general the three necessary reaction products would not be likely to be supplied under the right conditions. Even if such mutants were saved they would be difficult to analyze by the technique routinely used and would be likely to be put aside. There is no doubt that this objection is well taken. On the other hand, if one gene could direct the specificity of more than one enzyme, one might expect occasionally to find single gene mutants with double growth-factor requirements that could not be interpreted on the one-to-one hypothesis. The only clear cut mutant of this type so far analyzed is that requiring both isoleucine and valine for growth. Bonner (47) has shown that a reasonable explanation of it is possible in terms of one blocked reaction and hence one specific enzyme defect. It is clear that additional experimental evidence, possibly different in kind from that now available, is necessary before any decision can be made as to the generality of the one-to-one hypothesis.

The precise manner in which genes transfer their specificities to nongenic proteins remains almost a complete unknown. The answer to this question will almost certainly be essentially the same as the answer to the questions of how specific proteins in general are synthesized and how genes themselves are duplicated. Wrinch (59) has recently addressed herself to this general problem.

\section{Bacterial Genetics}

It has already been pointed out that bacterial genetics has only just become a socially acceptable field of interest. The extent to which the genetic viewpoint has affected bacteriology can be appreciated by reading Luria's recent valuable and stimulating review Recent Advances in Bacterial Genetics (1). While there are no compelling reasons for doubting that bacteria have genes essentially similar to those of higher organisms or that there exists some precise mechanism for distributing these hereditary units to daughter 
cells, there are a number of reasons why bacterial genetics appears superficially different from that of higher plants and animals. In the first place, observations are usually made on very large populations of bacteria, not on individual organisms. Such populations, whether they consist of colonies on a solid medium descended from single cells or suspensions of cells in a liquid medium, are usually of enormous size in terms of number of cells. With gene mutation rates of the same order as found in higher organisms, these populations will almost always be mixtures of diverse types, the proportions of the different types being determined by chance, relative mutation rates, and by selection pressures. Unlike higher multicellular organisms in which the germ line is differentiated early. in development of the individual, any cell in a bacterial population is capable of continuing the line. Finally, although there is now suggestive evidence of some type of fusion process or sexual reproduction in one strain of Escherichia coli $(60,61)$, there has not been known in bacteria a recognizable and experimentally controllable sexual process. Since in classical genetics the gene is a unit of inheritance experimentally defined in terms of sexual reproduction, bacterial genes have had to be investigated by indirect methods. In view of these considerations it is perhaps not remarkable that geneticists and bacteriologists have heretofore had little influence on one another.

The physical basis of inheritance in bacteria.-As a result of the remarkable work of Robinow (62) and others (63), it has become clear that at least certain of the rod-shaped bacteria have well defined chromosome-like structures that go through regular changes during the bacterial division cycle. It seems almost certain that these structures provide the physical basis of orderly gene distribution to daughter cells during fission. In view of these findings, it is not difficult to believe that such structures exist in all bacteria.

Parallelism of genetic phenomena in bacteria and higher organisms.- One of the indirect methods that has been resorted to in the study of bacterial genetics is that of mutation frequencies. If bacteria have genes like higher organisms that undergo random mutation at measureable rates, it should be possible to analyze bacterial populations in terms of such mutation rates. It is difficult to measure mutation rates in bacteria directly because the nature of any given individual must be inferred from the colony (population) it gives rise to, because mutation rates of individual genes are likely 
to be so low as to require an inordinate amount of work to measure them, and because the final equilibrium established in a bacterial population is almost always strongly influenced by selection pressures. In Serratia marcescens, color variations are frequent. Bunting (64) has shown that if populations of this bacterium are maintained in the logarithmic phase of growth under suitable conditions, there are no selection differentials among different color types and the equilibrium is dependent solely on relative mutation rates. Since these rates are high, they can be measured directly. From the final equilibrium established between red and pink types kept growing logarithmically the relative forward and back mutation rates for the red-to-pink change can be determined. The rate at which the final equilibrium is established is a measure of the absolute rates. The actual rates for the red-to-pink change and the reverse are $10^{-4}$ and $3 \times 10^{-3}$ per bacterium per cell generation. The hypothesis that color in this bacterium is gene-determined and that the genes concerned show random mutation at definite rates is clearly consistent with the facts. Braun's analysis (65) of rough-smooth variation in Brucella abortus shows that the phenomena concerned are capable of being accounted for in terms of gene mutations plus selection pressures.

In particular instances of bacterial variation the question has of ten arisen as to whether the change observed was a result of an environmentally induced modification or due to spontaneous and random "mutation." To distinguish between these possibilities, Luria \& Delbrück (118) have developed the so-called "fluctuation" test. This depends on the assumption that if a given variation is environmentally induced, the proportion of modified cells will be statistically constant from sample to sample whether these samples come from one or several clones. If, on the other hand, the change occurs spontaneously and at random, the frequency of modified cells will vary greatly from clone to clone depending on whether or not a mutation happened to occur early in clonal development. It is also possible by means of the Luria-Delbrück method to estimate mutation rates (1). This clonal grouping method has been applied to phage-resistance in Escherichia coli (1), to resistance to penicillin (1), and to sulfonamide in Staphylococcus (66), to resistance to radiation sterilization in $E$. coli $(67)$, to histidine independence in E. coli (38), and to uracil independence in Clostridium (68). In all instances the cellular modifications responsible for these changes 
were randomly distributed suggesting that they could have resulted from gene mutation. In all of these studies cultural conditions were purposely such as favor the selection of mutant types.

Witkin (67) has recently reported an interesting mutant type in Escherichia coli. As compared with the original, this mutant is much more resistant to sterilization by $\mathrm{x}$-rays or ultraviolet. Its susceptibility to $x$-ray or ultraviolet induced "gene" mutations, however, remains unchanged (69).

Following the demonstration that genes concerned with the synthesis of vitamins, amino acids and other metabolites could be induced to mutate with $\mathrm{x}$-rays and ultraviolet radiation, similar types of mutants were looked for in bacteria by Roepke et al. (119), Gray \& Tatum (120), Tatum (70), Burkholder \& Giles (71) and others. It is clear that essentially the same metabolic systems exist in $E$. coli as in the fungi Neurospora and Ophiostoma. For example, Lampen and his co-workers $(50,51,52)$ have shown that mutant strains of this bacterium with altered sulfur metabolism parallel closely mutants found in Neurospora (48) and in Ophiostoma (49). Similarly, the ornithine cycle made evident in $E$. coli through the study of mutant strains (70) is similar to that in Neurospora. Roepke (70) has shown that tryptophane synthesis in E. coli occurs in a manner similar to that in Neurospora. Tatum (70) cites several other examples of similar striking parallels. Since the various syntheses referred to can be shown by direct genetic methods to be gene-controlled in Neurospora and Ophiostoma, it seems almost inconceivable that the agents which direct the same chemical reactions in bacteria and show the same properties of mutation are not genes with essentially the properties of those of higher organisms.

Delayed appearance of induced mutants.-As already pointed out, phage-susceptible bacteria may spontaneously change to phage-resistant types by a gene-mutation-like process. Demerec (72) and Demerec \& Latarjet (69) have shown that the frequency of such mutations in Escherichia coli can be greatly increased with x-ray or ultraviolet treatment of bacteria. While making quantitative studies of the induction of such mutations, a phenomenon has been observed that may well contribute in an important way to an understanding of the division mechanism in bacteria. This is the phenomenon of the delayed appearance of induced mutations (69). Following raying in either the resting or growing condition, some induced phage-resistant mutants make 
their appearance in the treated cell generation, i.e., without division of the bacteria, but the majority do not show up until one or more divisions have ensued. Only after about thirteen cell generations does the observed mutation rate return to the spontaneous level.

As Demerec \& Latarjet (69) suggest, this result might be expected if the rayed bacterial population were heterogeneous with respect to the number of sets of hereditary units, i.e., were irregularly polyploid. Indeed Peshkoff's observations on Caryophanon latum (63) suggest that such a situation may exist in this bacterium. On the other hand, the expression of mutant changes may require the exhaustion of some substrate, and the time required for this may vary among individuals (69). Still another possibility is that the mutations may result indirectly through effects on the cytoplasm which may require several generations to disappear. In this connection a most interesting and significant discovery, made by Stone, Wyss \& Haas (73), is that mutations for penicillin and streptomycin resistance are induced in Staphylococcus aureus by $\mathrm{x}$-raying the medium in which the bacteria are subsequently placed. Here it is evident that the effect is indirect, possibly through the production of mutagenic substances in the medium. If such substances can be produced in the external medium it seems most likely that they would also be produced in the cytoplasm of a rayed cell and would result in delayed mutations such as Demerec \& Latarjet have reported (69).

Possibility of sexual phenomena in bacteria.-The existence of some form of sexual reproduction in bacteria has been suggested many times. In fact morphological and experimental evidence have been brought forward in a number of instances [see review by Luria (1) for discussion and references], but to most bacteriologists and others this evidence has not seemed convincing. Sherman \& Winge (74) appear to be the first workers to have used a genetic method in attempting to see if bacteria underwent any type of fusion and separation by which characters could be recombined. These experiments, made with the coli-aerogenes group and making use of the ability to utilize specific substrates as markers, gave inconclusive results because of instability of the parental lines. A similar approach to the problem was made by Gowen \& Lincoln (75) using Phytomonas stewartii as test material. No evidence of the occurrence of a heterozygous phase or of recombination of characters was obtained. 
Using growth-factor-requiring strains of $E$. coli, Lederberg \& Tatum $(60,61)$ have recently obtained convincing evidence of fusion and segregation. Since the frequency of recombination types is low (of the order of $10^{-7}$ ), it is necessary to use double or multiple mutant types as parents to exclude the possibility of reverse mutation as an explanation of the appearance of types having fewer mutant traits than either parent. The results appear to indicate true segregation. In fact, characters segregate in a nonrandom fashion indicative of a linkage mechanism of some sort (1). These findings are of revolutionary importance for they modify basic concepts regarding the biology of bacteria, particularly mechanisms of evolution, in these relatively simple organisms. Independent confirmation of the Lederberg-Tatum phenomenon is eagerly awaited, not because of any question as to the facts, but because of the great importance of the result and because of a natural question as to how widespread among bacteria the process is. In this connection it is of interest that Lederberg [unpublished result, cited by Luria (1)] and Luria (1) are unable to obtain similar results with another strain of $E$. coli.

\section{Genetics of Viruses}

Thirty years ago Troland, wrote with remarkable insight about the interrelations of genes, enzymes and the then newly discovered viruses. It is unfortunate that he did not live to learn how prophetic his words were. One of the most fascinating recent developments in genetics is the demonstration by Burnet (121), Luria (1), Delbrück $(76,77)$, Hershey $(78,79)$, and others that bacterial viruses are mutable and that their mutation characteristics can best be accounted for on the assumption that an individual virus particle carries several gene-like mutation sites. Related viruses that attack the bacterium E. coli, strain B, vary in morphology as determined by electron microscopy, in antigenic properties, in host specificity and in plaque (clear area produced by lysis of bacteria on a Petri dish culture) characteristics. Spontaneous mutations in host specificity and in plaque characters have been observed and studied by several investigators [see Delbrück (76) and Hershey (78) for recent reviews]. Hershey, for example, has shown that the mutation from slow-lysing to rapid-lysing types, accompanied by changes in plaque characters, occurs with a frequency of once per approxi- 
mately $10^{3}$ virus duplications. The reverse mutation is much less frequent, occurring about one time per $10^{8}$ duplications.

By the methods that he calls pattern analysis and rate analysis of mutant changes, Hershey $(78,79)$ has shown that lysis rate (detectable as a plaque character) and host range are independently mutating characters. It is found that the virus designated $\mathrm{T} 2 \mathrm{H}$, which has a certain host range and is a slow lyser, mutates spontaneously and irreversibly to one or another of two types with host ranges different from the original and from each other. All three host range types mutate reversibly to rapid lysers. A mutational change in lysis rate in the original $\mathrm{T} 2 \mathrm{H}$ has no effect on the tendency of the virus to give host-range mutations. The rate of one of the two host-range mutations is identical in slow and rapid lysing strains. Essentially similar arguments are used to show that there are two independently mutable host-range factors and at least three independent sites influencing lysis characteristics.

Recombination of characters.-If bacteria are infected with a mixture of viruses not closely related as judged by morphology and serological properties, only one of the two types is multiplied in a given bacterium, a phenomenon called mutual exclusion. The yield of the successful type may be reduced markedly by the unsuccessful competitor [see Delbrück (76) for review]. If, however, two virus strains used in mixed infection are closely related, both may multiply within a single bacterium $(76,78)$. Delbrück \& Bailey $(77)$ observed that if the related types that multiply in a single bacterium differ in lysis characteristics (detectable also as plaque differences), new types may emerge, recombining characters of the virus strains with which the mixed infection was made. Thus if a bacterium is infected with $\mathrm{T} 6 r$ and $\mathrm{T} 4 r^{+}\left(\mathrm{r}\right.$ and $\mathrm{r}^{+}$designate differences in plaque and lysing characteristics; T6 and T4 have different host specificities), the new types of $\mathrm{T}^{+} r^{+}$and $\mathrm{T} 4 r$ are obtained among the progeny. The data of Delbrück \& Bailey do not distinguish between induction of mutation in one phage by another multiplying in the same cell and recombination of virus elements. Hershey (78) has, however, reported experiments in which two viruses involved in mixed infection were strains of $\mathrm{T} 2 \mathrm{H}$ differing in three characters and the results of these point to a recombination phenomenon of some sort. Thus, where one infecting virus was $h c^{+} h b^{+} r$ and the other $h c h b r^{+}$, where $h c$ and $h b$ refer to host spec- 
ificity characters and $r$ to lysis rate and plaque-type, seven phenotypes were recovered where eight would be predicted with free recombination.

Luria (79a) has recently made a preliminary report on his most remarkable discovery that two phage particles, each inactivated by ultraviolet radiation with respect to ability to multiply when absorbed by different sensitive bacterial cells, can somehow become reactivated when both are absorbed by the same cell. It is suggested by Luria that reactivation involves some type of recombination of gene-like loci that have undergone lethal mutation. $X$-ray inactivated phages cannot be reactivated in double or multiple infections.

These exciting results strongly suggest that bacterial viruses are structures containing at least several gene-like subunits. With the abundant experimental material available and the most elegant techniques developed by bacterial virus workers, the new field of virus genetics can be expected to develop rapidly.

\section{Chemrally Induced Mutations}

Nonspecific agents.-During the past twenty-five years or more numerous attempts have been made to induce gene mutations with various chemical agents. Almost all of these have either met with failure or the effects were so slight as to be of doubtful significance. The nucleus of higher plant and animal cells appears to be remarkably well insulated against changes in its chemical environment sufficient to modify genes. The first report of success came from the experiments of Auerbach \& Robson, on Drosophila melanogaster, in which mustard oil was used. Later, when security regulations were relaxed, it was disclosed that mustard gas $\left(\beta, \beta^{\prime}\right.$-dichlorodiethyl sulfide) was much more effective ( 80$)$. This was administered as a vapor. The incidence of sex-linked lethals was increased from 0.2 per cent in the controls to as high as 24 per cent in the treated series. Subsequent tests of related compounds showed that several of the nitrogen- or sulfur-mustard gases, e.g., $\beta, \beta^{\prime}$-dichlorodiethylmethylamine, were also active. Subsequent studies by Auerbach \& Robson $(81,82,83)$ have shown that nonlethal gene mutations, resulting in morphological characters, as well as chromosome aberrations are produced by mustard gases. Like those of $\mathrm{x}$-rays the effects are nonspecific. Treatment of unfertilized eggs gave no increase in mutation frequency in paternal chromosomes subsequently introduced through the fertilizing sperm, suggesting that 
the mustard gas effect is directly on the chromosomes. A similar conclusion has been drawn by Muller and by Timofeeff-Ressovsky regarding x-ray effects. It is not obvious how this result is to be reconciled with the observation of Stone, Wyss \& Haas (73) that mutations are produced in bacteria by raying the culture medium and subsequently introducing the bacteria.

The effect of mustard gas on chromosome rearrangement has been confirmed by Koller working with the plant Tradescantia [cited by Auerbach et al. (83)]. Demerec (84) has found that lethal mutations are produced in Drosophila, while Horowitz et al. (85) have shown that biochemical mutations are produced in Neurospora. Tatum has concluded that the nitrogen mustard gas, $\beta, \beta^{\prime}-$ dichlorodiethylmethylamine, induces mutation in Neurospora (46) and in Escherichia coli (70), although the preliminary reports of this work give no data on mutation frequencies in untreated controls.

The somatic mutation theory of the origin of cancer cells has been considered many times. One of the objections to it has been the lack of mutation-producing effect of carcinogenic chemical substances. Demerec (84) has just recently reported that 1,2,5,6dibenzanthracene, a known carcinogenic substance, applied to Drosophila as an aerosol of a solution in oil increases the incidence of sex-linked lethals by a factor of approximately twenty and that it also produces chromosome breaks. Strong (85a) had previously reported that the carcinogen methylcholanthrene induces coat color and other mutations in mice but because the rigorous genetic control that can be had in Drosophila is not possible in mice, there was some basis for skepticism regarding the mouse results. The results of experiments planned to correlate the mutagenic and carcinogenic activities of various compounds will be of great interest for they will provide important evidence for or against the somatic mutation theory of cancer.

Hadorn \& Niggli (86) have reported that phenol induces mutations in Drosophila in excised ovaries treated with a dilute solution and implanted in untreated females. No confirmation of this reported mutagenic property of phenol has appeared to the reviewer's knowledge.

The experiments of Stone, Wyss \& Haas in which mutations were induced in bacteria by $x$-raying the culture medium have already been mentioned. It has not yet been reported whether the effect in this instance is specific or nonspecific. 
Specific agents.--Interest in pneumococcus-transforming principle continues at a high level. McCarty \& Avery $(87,88)$ have made further studies of these high polymers of desoxyribonucleic acid that in the presence of serum or serous fluids have the property of directing mutations of noncapsulated avirulent strains of pneumococcus to types specific with respect to the polysaccharide capsule. It has been shown that the transforming principle from Type III organisms is rapidly inactivated by minute amounts of purified desoxyribonuclease under conditions known to favor enzyme activity but not under those known to inhibit it. This evidence still further strengthens the argument that the transforming principle is the nucleic acid polymer and not an impurity. Transforming principles have been isolated from Types II and VI pneumococci and, like that for Type III, shown to be highly polymerized nucleic acids. A general review of the subject has been prepared by McCarty (89).

Whether the type-specific nucleic acids of pneumococci act by directing gene mutations, or are themselves taken up by the transformed organism to become a part of its gene system remains an unanswered question. In any event it seems clear that they do not serve merely as selection agents for mutations that would have occurred spontaneously. The fluid components have been investigated by McCarty, Taylor \& Avery (90), who found that there are at least three of these, viz., the $\mathrm{R}$ antibody, a second protein component and a dializable factor.

Boivin, Delaunay, Vendrely \& Lehoult $(91,92,93)$ have reported evidence favoring the view that mutations in $E$. coli from noncapsulated to capsulated forms can be directed with respect to capsular antigens by a desoxyribonucleic acid fraction. In this case serum factors are not necessary for the transformation to occur but it is essential that the bacteria be in a "susceptible" condition, not yet completely defined experimentally. The evidence that Escherichia transforming factors are nucleic acid is not as complete as that for pneumococcus.

Certain of the implications of the directed transformations in pneumococcus and Escherichia are obvious. A high degree of biological specificity, formerly thought to be limited to proteins and polysaccharides, can evidently be manifested by polymers of nucleic acid. Whether this specificity lies in chemical makeup of these molecules or in their physical configurations remains to be deter- 
mined. As a result of this newly acquired knowledge we are certainly one step closer to an understanding of the gene and the mutation process.

\section{Cytoplasmic Inheritance}

There is a tremendous body of experimental evidence indicating that in higher plants and animals the stable hereditary mechanism consists of nuclear genes. On the other hand, every intelligent biologist has appreciated that cytoplasm is an essential medium through which genes act, that it has a certain amount of autonomy, and that it is of great importance in the process of differentiation. During recent years the interest of geneticists has been turned toward the cytoplasm by a number of instances of cytoplasmically inherited traits.

The fact that plastids arise only from pre-existing plastid or plastid primordia, and that mutation-like defects in these bodies, not reversible by nuclear genes, may occur and be transmitted for many cell and plant generations has been known for a long time. Rhoades (94) has recently reviewed our knowledge of the interrelation between higher plant plastids and nuclear genes.

The killer character in Paramecium.-Another interesting instance of cytoplasmic inheritance is that involving the so-called killer character in Paramecium aurelia studied by Sonneborn and his associates $(95,96)$. It is found that in a number of varieties of this protozoan there are two kinds of individuals, killers and sensitives. Killers produce a substance in the medium that kills individuals of a sensitive strain in a characteristic way. It has been shown that the killer character is dependent on a cytoplasmic component, called kappa, and a nuclear gene $+^{k}$. Kappa can only be multiplied if allele $+^{k}$ is present in the nuclei but it cannot be initiated by this allele; that is, some kappa must be present for more to be produced. If allele $t^{k}$ is replaced by $k$, an alternate form of the same gene, kappa is no longer multiplied. Preer $(97)$ and Sonneborn $(95,96)$ have shown that in $+^{k}$ animals containing kappa, the multiplication of kappa need not keep pace with multiplication of the entire organism. Thus in variety 2 Preer finds that well-fed organisms kept under favorable conditions increase faster than kappa can multiply. By a series of ingenious experiments Preer was able to show that there are about 250 kappa particles in killer animals, - that if this number is reduced below a threshold the animal be- 


\section{4}

comes a sensitive that can revert to a killer if its division rate is. reduced, and that if a high division rate is maintained for a sufficient time, some animals run out of kappa entirely and become permanent sensitives. He was able to show that an individual with only a single kappa particle is capable of reverting to a sensitive. Working with variety 4 , Sonneborn has confirmed Preer's findings. Killers of this variety cannot be made to outgrow their kappa by optimal feeding but can be made to do so by growing them at a temperature of $38.5^{\circ} \mathrm{C}$. If maintained for three to four days, this temperature is lethal, but if killers are exposed to it for shorter times, kappa is reduced in amount or eliminated. Thus after twelve hours killers become sensitives that can be reversed while after thirty-six hours they become permanently sensitive. Kappa can be transferred to $+^{k}+^{k}$ sensitive animal through the cytoplasmic bridge that may be formed during conjugation of the $+^{k}+^{k}$ sensitive (no kappa) animal with $+^{k}+^{k}$ (with kappa) animal. In this way Sonneborn has succeeded in transferring as few as two to four kappa particles. These leave the animal that received them sensitive but capable of becoming a killer when the fission rate drops at autogamy or during old age sufficiently to allow kappa multiplication to exceed cell fission by six or seven times-that is, when the number of kappa particles is increased to approximately $256\left(2^{8}\right)$.

It is found by Sonneborn $(95,96)$ that all characters investigated in the $B$ group of varieties, to which variety 4 belongs, involve a kappa-like cytoplasmic determinant. These characters include the killer character, antigenic properties and mating type. There is no evidence of comparable cytoplasmic units for similar characters in group A varieties.

Other instances of cytoplasmic inheritance.-Sonneborn (96) and others have found that resistance of a strain of Paramecium aurelia to antiserum directed against the same strain may be induced by treatment of the susceptible animals with the antiserum. Such resistance is known to be transmitted through many vegetative fissions, but not through sexual reproductions. Kimball (98) has observed that resistance is also induced by treatment with trypsin. It is supposed that susceptibility is dependent on an antigen which may be temporarily depleted through combination with antibodies or by tryptic digestion of the antigen itself or a precursor of it. Whatever is destroyed by trypsin is supposed by Kimball to be formed autocatalytically for it would otherwise be expected to 
reappear after very few fissions. It is interesting to note that crosses between strains susceptible to antiserum against stock 60 , variety 1 , and others resistant to such an antiserum show the antigen concerned to be gene-controlled.

L'Heritier and his associates $(99,100)$ have for some years concerned themselves with the inheritance of susceptibility to carbon dioxide in Drosophila melanogaster. This trait is transmitted from generation to generation independently of chromosomes and apparently through the cytoplasm. It is much more effectively carried through the egg than through the sperm as would be expected if it were a cytoplasmic entity. Its sensitivity may be abolished temporarily or permanently by subjecting affected flies to either high or low temperatures and can be transmitted from an affected animal to a resistant one through ovary or brain transplants or through transfer of cell-free lymph [work cited by Ephrussi in discussion of paper by Sonneborn (95)]. The carbon dioxide-susceptibility character is apparently subject to an interpretation similar to that advanced for the killer character in Paramecium (100). Other instances of supposed cytoplasmic inheritance are those in wheat and oat rusts recently summarized by Johnson (101). These involve the transmission of pathogenic characteristics.

Mampell (102) has continued his studies on a strain of Drosophila pseudoobscura showing a high spontaneous mutation rate. $\mathrm{He}$ postulates the existence of both a mutator gene and a cytoplasmic component that can be transferred by contact from one strain to another or even from Drosophila pseudoobscura to Drosophila melanogaster. The situation is not yet well understood and the evidence for the self-reproducing cytoplasmic factor postulated by Mampell is not entirely convincing.

It is, I believe, cause for reflection that none of the instances in which cytoplasmic inheritance is firmly established is a selfduplicating gene-like structure involved that cannot reasonably be supposed to be gene-dependent. Thus, while Sonneborn's kappa is certainly self-duplicating in the sense that some must be present before more can be formed, it cannot continue to be elaborated in the absence of the $+^{*}$ allele of a specific gene. It is true that such gene-dependence has not always been demonstrated, but as Sonneborn (96) has pointed out this may mean merely that the active forms of all essential genes are present in all strains investigated. An alleged case of cytoplasmic transmission that would seem to the 
reviewer to require a basic change in our conceptions of genic control is that first reported by Lindegren, Spiegelman \& Lindegren $(103,104)$ in yeasts. Here, it is claimed, there exists an enzyme melibiase that in the presence of the substrate melibiose is capable of indefinite self-duplication in the absence of the gene that initiates it. It is true that the supposed self-duplicating cytoplasmic entity may be an enzyme precursor rather than the enzyme itself but it remains that we have here a postulated cytoplasmic unit that is capable of permanently substituting for a gene. There has been a great deal of discussion of this situation (105). In fact an elaborate theory (the so-called cytogene theory) has been developed as a result of the reported facts $(106,107)$. It appears from a recent publication of Lindegren \& Lindegren (107) that the critical experiments on which the self-duplicating enzyme hypothesis was based cannot be repeated. The cytogene theory has apparently been abandoned (45). Evidently a final appraisal of the situation in yeast must await the straightening out of the basic experimental facts.

Symbiosis and the origin of cytoplasmic hereditary units.Altenburg (108) has suggested that cytoplasmic factors like kappa in Paramecium might well have arisen from symbionts such as the green algae found in Paramecium bursaria. While, as Sonneborn (96) has pointed out, strong arguments can be advanced against such an interpretation in the case of the killer character, it is not easy to rule out the symbiont hypothesis completely. In fact, on logical grounds one would expect in certain cases the genes of an intracellular symbiont to take over the functions of one or more genes of the host organism. This has apparently occurred in the cockroaches where bacteria-like organisms live symbiotically in the fat body cells of the insect. The "bacteroids" have not been cultivated in the absence of living cells nor can the host live if the symbionts are abolished by penicillin treatment (109). Apparently each of the symbiotic partners has become irreversibly dependent, presumably through a process of complementary gene mutation. The cockroach is dependent on genes of the bacteria and vice versa. The degenerate bacteria are transmitted cytoplasmically through the egg of the insect. If the intracellular symbiont were to retrogress somewhat further, affect the host in a nonvital manner and to be less obviously descended from a bacterium, one would certainly conclude that it constituted a self-duplicating cytoplasmic hereditary factor. 
How general is cyloplasmic inheritance?-However gene-like cytoplasmic hereditary units may arise, it does not seem likely that they are of widespread occurrence. If self-duplicating enzymes or enzyme precursors of the Spiegelman-Lindegren variety were the rule we would not expect experimentally to find the numerous biochemical mutants that have been demonstrated in Neurospora and Ophiostoma and which differ in nuclear genes from their synthetically more complete counterparts. Furthermore we should expect to find many deficiency mutants that differ from the original type only in a cytoplasmic component. It seems highly probable, as Sonneborn (96) and others have pointed out, that cytoplasmic substitutes for nuclear genes would become established only under special circumstances. The ciliates in which a division of labor between two kinds of nuclei has become established might well constitute just such a special case. The almost universal distribution among existing organisms of the nuclear gene mechanism of heredity is good evidence that it represents the most effective machinery that mutation and natural selection have so far succeeded in devising.

Plasmagenes in another sense.-It seems entirely possible that many nuclear genes may direct the synthesis of elements capable of multiplication in the cytoplasm. As Wright (110), Burnet (111), Spiegelman (104), Boivin \& Vendrely (112), and others have pointed out, this assumption is not unreasonable on the basis of our knowledge of phenomena such as cellular differentiation and the multiplication of adaptive enzymes. Wright (110) has indicated how such gene-initiated self-duplicating cytoplasmic elements, which have been called plasmagenes, might, under the influence of local environmental conditions in a developing organism, become systematically modified without losing the ability to multiply. An orderly succession of such modifications might well underlie the process of differentiation. Plasmagenes in this sense are not cytoplasmic substitutes for nuclear genes but rather are complementary to them.

\section{Evolutionary Considerations}

The Horowitz hypothesis (113) which has to do with the evolutionary history of systems of biosynthetic reactions was mentioned in a previous volume of this series (2). There are two recent contributions that have a bearing on this general question. One is the observation by Monod (114) that a methionine-requiring 
Aerobacter mutant grows appreciably faster on a methionine-containing medium than does the wild type strain from which it was derived. One cannot, of course, generalize from a single instance of this kind, but it would be most significant from the standpoint of evolution if it were frequently the case that loss mutants were more successful than their synthetically more complete counterparts in an environment rich in the product of the reaction blocked in the mutant. It is of course a well known fact, as has been pointed out especially by Lwoff (115) and by Knight (115a), that evolutionary specialization through loss of synthetic ability has occurred in many groups of organisms. It seems probable that genes that become inactive in this process are available for mutations that add new synthetic reactions and thus serve to make possible positive evolution (116).

Houlahan \& Mitchell (117) have reported a situation in Neurospora that may have an important bearing on the question of positive evolution. It is found that the pyrimidine requirement of a mutant strain can be abolished through mutation of a gene that is genetically independent of the one involved in the original $\mathrm{mu}$ tant change from wild type. Such "suppressors" have been known for a number of mutant traits in Drosophila but this is one of the clearest so far as knowing the affected system of synthesis is concerned. If the normal function of one gene can be taken over by a mutant form of another, it seems possible that the direction of an entirely new reaction could be taken over by an unneeded gene in essentially the same manner. 


\section{LITERATURE CITED}

1. LuRia, S. E., Bact. Revs., 11, 1-40 (1947)

2. Danf,orth, C. H., Ann. Rev. Physiol., 8, 17-42 (1946)

3. Muller, H. J., Proc. Roy. Soc. (London) [B]134, 1-37 (1947)

4. Mather, K., Sci. J. Roy. Coll. Sci., 16, 63-71 (1946)

5. Beadle, G. W., Chem. Revs., 37, 15-96 (1945)

6. Beadle, G. W., Proc. Am. Phil. Soc., 90, 422-31 (1946)

7. Beadle, G. W., In Currents in Biochemical Research, 1-12 (Interscience Pub. Inc., N. Y., 1946)

8. BeAdle, G. W., Medicina, 7, 172-83 (1947)

9. FISHER, R. A., Heredity, 1, 1-17 (1947)

10. Buzzati-Traverso, A., Heredity, 1, 19-51 (1947)

11. Demerec, M., "Heredity and Variation in Microorganisms," Cold Spring Harbor Symposia Quant. Biol., 11, 314 pp. (1947)

11a. Danielli, J. F., AND Browne, R. (Editors), "Nucleic Acid," Symposia Soc. Exptl. Biol., 1, 1-290 (Cambridge Univ. Press, Cambridge, England, 1947)

12. Stern, K., Goldstein, G., Wagman, J., And Schryver, J., Federation Proc., 6, 296 (1947)

13. Mirsky, A. E., Pollister, A. W., ANd Ris, H., Genetics, 31, 224-25 (1946)

14. Mirsky, A. E., ANd Pollister, A. W., J. Gen. Physiol., 30, 117-48 (1946)

15. Stedman, E., ANd Stedman, E., Nature, 152, 267-69 (1943)

16. IRwin, M. R., Biol. Revs., 21, 93-100 (1946)

17. IRwin, M. R., Advances in Genetics, 1, 133-59 (1947)

18. IrWin, M. R., AND CuMLEy, R. W., Genetics, 32, 178-84 (1947)

19. Race, R. R., Mourant, A. E., and Callender, S., Nature, 157, 410-11 (1946)

20. Wiener, A. S., Sonn, E. B., And Polivka, H. R., Proc. Soc. Exptl. Biol. Med., 61, 382-91 (1946)

21. FISHER, R. A., Am. Scientist, 35, 95-102; 113 (1947)

22. Stern, C., Schaeffer, E. W., and Heidenthal, G., Proc. Natl. Acad. Sci. U. S., 32, 26-33 (1946)

23. Stern, C., MacKnight, R. H., and Kodani, M., Genetics, 31, 598-619 (1946)

24. Gersh, E. S., ANd EpHrussi, B., Proc. Natl. Acad. Sci. U. S., 32, 87 94 (1946)

25. GoldschmidT, R., Experientia, 2, 197-203, 250-56 (1946).

26. Russell, E. S., Genetics, 31, 327-46 (1946)

27. Wald, G., And Gordon, A., J. Gen. Physiol., 30, 41-46 (1946)

28. CAspari, E., Genetics, 31, 454-74 (1946)

29. Green, M. M., Genetics, 31, 1-20 (1946)

30. BLANC, R., Genetics, 31, 395-420 (1946)

31. Stadler, L. J., Genetics, 31, 377-94 (1946)

32. Hollaender, A., and Swanson, C. P., Genetics, 32, 90 (1947)

33. Beadle, G. W., ANd Tatum, E. L., Am. J. Botany, 32, 378-86 (1945)

34. FrIes, N., Nature, 155, 757-58 (1945)

35. Fries, N., Nature, 159, 199 (1947)

36. Lederberg, J., and Tatum, E. L., J. Biol. Chem., 165, 381-82 (1946) 
37. Ryan, F. J., ANd Lederberg, J., Proc. Natl. Acad. Sci. U. S., 32, 163-73 (1946)

38. Ryan, F. J., Cold Spring Harbor Symposia Quant. Biol., 11, 215-26 (1946)

39. TATum, E. L., AND Bell, T. T., Am. J. Botany, 33, 15-20 (1946)

40. Horowitz, N. H., J. Biol. Chem. 162, 413-19 (1946)

41. Mitchell, H. K., and Houlahan, M. B., Am. J. Botany, 33, 31-35 (1946)

42. Bonner, D., ann Beadle, G. W., Arch. Biochem., 11, 319-28 (1946)

43. Beadle, G. W., Mrtcheld, H. K., and Nyc, J. F., Proc. Natl. Alcad. Sci. U. S., 33, 155-58 (1947)

44. Bonner, D., Am. J. Botany, 33, 788-91 (1946)

45. Lindegren, C. C., ANd Lindegren, G., Ann. Missouri Botan. Garden, 34, 95-99 (1947)

46. Bonner, D., Cold Spring Harbor Symposia Quant. Biol., 11, 14-22 (1946)

47. Bonner, D., J. Biol. Chem., 166, 545-54 (1946)

48. Horowrtz, N. H., Federation Proc., 6, 262-63 (1947)

49. FrIEs, N., Svensk Botan. Tid., 40, 127-40 (1946)

50. Lampen, J. O., ANd Jones, M. J., Arch Biochem., 13, 47-53 (1947)

51. Lampen, J. O., Jones, M. J., and Perkins, A. B., Arch. Biochem., 13, 33-45 (1947)

52, Lampen, J. O., Roepke, R. R., and Jones, M. J., Arch. Biochem., 13, 55-66 (1947)

53. Mitchell, H. K., And Houlahan, M. B., Federation Proc., 5, 370-75 (1946)

54. FrIEs, N., Arkiv Botan. 33, 1-7 (1946)

55. Emerson, S., And Cushing, J. E., Federation Proc., 5, (379-89 (1946)

56. EMERson, S., J. Bact. (In press)

57. McElrox, W. D., ANd Mitchell, H. K., Federation Proc., 5, 376-79 (1946)

58. Ginsburg, B., AND Kaplan, F., Genetics, 32, 87-88 (1947)

59. Wrinch, D., Science, 106, 73-76 (1947)

60. LederberG, J., AND Tatum, E. L., Nature, 158, 558 (1946)

61. Lederberg, J., and Tatum, E. L., Cold Spring Harbor Symposia Quant. Biol., 11, 113-14 (1946)

62. Rosinow, C. F., in Dubos: The Bacterial Cell, 356-77 (Harvard Univ. Press, Cambridge, Mass., 1945)

63. Peshroff, M. A., Nature, 157, 137-38 (1946)

64. Bunting, M. I., Cold Spring Harbor Symposia Quant. Biol., 11, 25-32 (1946)

65. Braun, W., J. Bact., 51, 327-49 (1946)

66. OAKBerg, E. F., ANd LuRIA, S. E., Genetics, 32, 249-61 (1947)

67. Witkin, E. M., Genetics, 32, 221-48 (1947)

68. Ryan, F. J., Schneider, L. K., ANd Ballentine, R., Proc. Natl. Acad. Sci. U. S., 32, 261-71 (1946)

69. Demerec, M., ANd Latarjet, R., Cold Spring Harbor Symposia Quant. Biol., 11, 38-49 (1946)

70. TATUM, E. L., Cold Spring Harbor Symposia Quant. Biol., 11, 273-83 (1946)

71. BURKholder, P. R., AND Giles, N. H., Am. J. Botany, 34, 34,5-48 (1947)

72. Demerec, M., Proc. Natl. Acad". Sci. U. S., 32, 36-46 (1946)

73. Stone, W. S., Wyss, O., and HaAs, F., Proc. Natl. Acad. Sci. U. S., 33, 5966 (1947)

74. Sherman, J. M., AND Winge, H. V., J. Bact., 33, 315-21 (1937) 
75. GoweN, J. W., ANd LinCoLN, R. E., J. Bact., 44, 551-54 (1942)

76. Delbrǘck, M., Bact. Revs., 21, 30-40 (1946)

77. Delbrǘck, M., and BaILey, W. T., JR., Cold Spring Harbor Symposia Quant. Biol., 11, 33-37 (1946)

78. Hershey, A. D., Cold Spring Harbor Symposia Quant. Biol., 11, 67-76 (1946)

79. Hershex, A. D., Genetics, 31, 620-40 (1946)

79a. Luria, S. E., Soc. Am. Bacteriologists Abst. Proc. May 13-16, 1947 meeting, 79 (1947)

80. Auerbach, C., and Robson, J. M., Nature, 157, 302 (1946)

81. Auerbach, C., and Robson, J. M., Proc. Roy. Soc. Edinburgh [B] 62, 271-83 (1947)

82. Auerbach, C., And Robson, J. M., Proc. Roy. Soc. Edinburgh [B] 62, 284-91 (1947)

83. Auerbach, C., Robson, J. M., and Carr, J. G., Science, 105, 243-47 (1947)

84. Démerec, M., Nature, 159, 604 (1947)

85. Horowitz, N. H., Houlahan, M. B., Hungate, M. G., and Wright, B., Science, 104, 233-34 (1946)

85a. Strong, L. C., Genetics, 32, 108 (1947)

86. HADORN, E., AND NIGGLI, H., Nature, 157, 162-63 (1946)

87. McCarty, M., AND Avery, O. T., J. Exptl. Med., 83, 89-96 (1946)

88. McCarty, M., AND Avery, O. T., J. Exptl. Med., 83, 97-104 (1946)

89. MCCarTy, M., Bact. Revs., 10, 63-71 (1946)

90. McCarty, M., Taylor, H. E., ANd Avery, O. T., Cold Spring Harbor Symposia Quant. Biol., 11, 177-83 (1946)

91. Boivin, A., Delaunay, A., Vendrely, R., ANd Lehoult, Y., Experientia, $1,334-35$ (1945)

92. Boivin, A., Delaunay, A., Vendrely, R., and Lehoult, Y., Compt. rend., 221, 718-19 (1945)

93. Boivin, A., Delaunay, A., Vendrely, R., and Lehoult, Y., Experientia, 2, 139-40 (1946)

94. Rhoades, M. M., Cold Spring Harbor Symposia Quant. Biol., 11, 202-7 (1946)

95. Sonneborn, T. M., Cold Spring Harbor Symposia Quant. Biol., 11, 236-48 (1946)

96. Sonneborn, T. M., Advances in Genetics, 1, 264-358 (1947)

97. Preer, J. R., Proc. Natl. Acad. Sci. U. S., 32, 247-53 (1946)

98. Kimball, R. F., Genetics, 32, 93 (1947)

99. L'Heritier, P., AND TeIssife, G., Pubs. lab. l'ecole nor male superieure, Biol., 1, 35-76 (1944)

100. L'Heritier, P., AND DE Scoeux, F. H., Nature, 157, 729 (1946)

101. Johnson, T., Cold Spring Harbor Symposia Quant. Biol., 11, 85-93 (1946)

102. MAMpelL, K., Genetics, 31, 589-97 (1946)

103. Lindegren, C. C., Bact. Revs., 9, 111-70 (1945)

104. SpIegelman, S., Cold Spring Harbor Symposia Quant. Biol., 11, 256-74 (1946)

105. Spiegelman, S., and Kamen, M. D., Science, 104, 581-84 (1946)

106. Lindegren, C. C., Proc. Natl. Acad. Sci. U. S., 32, 68-70 (1946)

107. Lindegren, C. C., ANd Lindegren, G., Cold Spring Harbor Symposia Quant. Biol., 11, 115-27 (1946) 
108. Altenburg, E., Am. Naturalist, 80, 559-67 (1946)

109. Brues, C. T., And Dunn, R. C., Science, 101, 336-37 (1945)

110. Wright, S., Am. Naturalist, 79, 289-303 (1945)

111. Burnet, F. M., Australian J. Sci., 8, 143-46 (1946)

112. Borvin, A., AND VeNDrely, R., Experientia, 3, 32-34 (1947)

113. Horowitz, N. H., Proc. Natl. Acad. Sci. U. S., 31, 153-57 (1945)

114. Monod, J., Ann. inst. Pasteur, 72, 889-890 (1946)

115. Lwoff, A., Cold Spring Harbor Symposia Quant. Biol., 11, 139-53 (1946)

115a. KNight, B. C. J. G., Bacterial Nutrition, 182 pp. (Med. Research Council, Brit., Special Rept. Ser. No. 210, 1936)

116. WeIR, J. A., Genetics, 32, 111-12 (1947)

117. Houlahan, M. B., And Mitchell, H. K., Proc. Natl. Acad. Sci. U. S., 33, 223-29 (1947)

118. LURIA S. E., AND Delbrück, M., Genetics, 28, 491-511 (1943)

119. RoEPKE, R. R., LibBy, R. L., AND SMall, M. H., J. Bact., 48, 401-12 (1944)

120. Gray, C. H., and Tatum, E. L., Proc. Natl. Acad. Sci., U. S., 30, 404-10 (1944)

121. BuRnet, F. M., J. Path. Bact., 32, 15-42 (1929) 


\section{CONTENTS}

PAGE

Biological Oxidations and Reductions, $H$. Weil-Malherbe . . . . . . . . . . . . . . 1

Nonoxidative Enzymes, $J$. B. Sumner . . . . . . $\quad 35$

Chemistry of the Carbohydrates, $D$. A. Prins and $R$. $W$. Jeanloz . . . . . . . . . . . . . . 67

The Chemistry of the Immunopolysaccharides, $W . N$. Haworth and M. Stacey . . . . . . . . . . . . 97

X-Ray Crystallographic Studies of Compounds of Biochemical Interest, $D$. Crowfoot . . . . . 115

Chemistruy of the Lipids, J. Folch-Pi and W. M. Sperry . 147

The Chemistry of the Proteins and Amino Acids, $K . O$. Pedersen. . . . . . . . . . . . . . 169

Nucleoproteins, Nucleic Acids, and Related SubSTANCES, E. Chargaff and E. Vischer . . . . . . . 201

Carbohydrate Metabolism, B. Vennesiand. . . . . 227

Lipid Metabolism, I. L. Chaikoff and C. Entenman . . 253

The Metabolism of Proteins and Amino Acids, $J$. B. $A l$ lison . . . . . . . . . . . . . . . 275

The Metabolism of Drugs and Toxic Substances, $O$. Bodansky . . . . . . . . . . . . . 303

Clinical Applications of Brochemistry, $L . J$. Zeldis and S. C. Madden . . . . . . . . . . . . 327

Biochemistry of the Hormones, T. F. Gallagher . . . . 349

The Vitamins, B. L. Oser . . . . . . . . . . . . . 381

Clinical Aspects of Vitamins, T. D. Spies . . . . . . 449

The Biochemistry of Carcinogenesis, $H$. $P$. Rusch and G. A. LePage . . . . . . . . . . . . 471

Biochemistry of the Natural Pigments, E. Lederer . . 495

The Terpenes (in Relation to the Biology of Genus Pinus), N. T. Mirov . . . . . . . . . . 521

The Alkaloids, $R$. F. Dawson . . . . . . . . . . 541

Photosynthesis, E. C. Wassink . . . . . . . . . . . $\quad .559$

Mineral Nutrition of Plants, H. Burström . . . $\quad$. 579

Plant Hormones, P. W. Zimmerman and A. E. Hitchcock. 601

Bacterial Metabolism, I. C. Gunsalus . . . . . . 627

The Chemistry of Penicillin, E. Chain . . . . . 657

Ruminant Digestion, S. R. Elsden and A. T. Phillipson . 705

Physiological Aspects of Genetics, G. W. Beadle . . 727

INDEXES . . . . . . . . . . . . . . . 753 